\title{
Previous Years Audit Opinions, Profitability, Audit Tenure and Quality Control System on Going Concern Audit Opinion
}

\author{
Aji Purnama Ramadhan and Mahendro Sumardjo
}

\section{ABSTRACT}

\begin{abstract}
This study was conducted to examine the effect of the previous year's audit opinion, profitability, audit tenure, and quality control systems on going concern audit opinion. This study uses mining sector companies and public accounting firms (PAF) that audited as samples in the study. The data analysis technique used is Path Analysis with Smart PLS 3 with a significance level of $5 \%$. The result indicates that previous year's audit opinion, profitability has a significant impact on going concern audit opinion, meanwhile, audit tenure and quality control system have not significant. Furthermore, other results from this study indicate that the audit tenure, quality control system, and previous year's audit opinion through the quality control system has no effect on going concern audit opinion. The implication of this study to the company is expected to pay attention to various factors, especially financial conditions that can have an influence on going concern audit opinion because this opinion gives a warning to the company.
\end{abstract}

Keywords: Previous Year's Audit Opinion, Profitability, Audit Tenure, Quality Control System, Going Concern Audit Opinion.

\author{
Submitted : March 17, 2021 \\ Published : April 07, 2021 \\ ISSN: $2507-1076$ \\ DOI: $10.24018 /$ ejbmr.2021.6.2.817 \\ Aji Purnama Ramadhan* \\ Universitas Pembangunan Nasional \\ Veteran Jakarta, Indonesia. \\ (e-mail: ajipurnama59@gmail.com) \\ Mahendro Sumardjo \\ Universitas Pembangunan Nasional \\ Veteran Jakarta, Indonesia. \\ (e-mail: sumardjo@yahoo.com)
}

*Corresponding Author

\section{INTRODUCTION}

Due to the information asymmetry, it does not avoid the possibility of a conflict between then principal and agent, where the agent tries to use the weakness of the other party for his benefit. In this case, the auditor can play a role as a third party who is expected to resolve the conflict of interest between the agent and the principal. As an independent party, the auditor is responsible for assessing whether the policies implemented by management have met the client's wishes. The auditor will check the fairness of the financial reporting that has been prepared by management.

In Indonesia there is problem in mining companies which is PT Timah Tbk (TINS) from the Kompas.com website (2020) just released its 2019 financial report. Apart from the Rp 611.28 billion net loss in 2019, Timah's management revised the data from the restated 2018 financial statements. The revision resulted in a profit net TINS in 2018 decreased by 73.67 percent when compared to the acquisition in 2017 which amounted to Rp 502.43 billion. If the recording error did not occur, perhaps TINS 'share price ahead of the announcement of the 2018 financial statements would not increase significantly. The auditors also show indications that the company is unable to maintain its business continuity.

Related to this, the company has made strategic efforts to maintain the continuity of the company's business and management believes that these efforts are the best currently available to overcome the problems faced by the company. The next case comes from Investor.id PT Bumi Resources
Tbk (BUMI) recorded a net loss of US \$ 137.3 million in the third quarter of 2020, inversely proportional to the same period in 2019 which earned a net profit of US \$ 76.1 million. This is due to three factors, namely the weakening of coal prices, lower sales volume, and debt repayment. Sales volume through September 2020 decreased by 5\%. According to Dileep, the decline in sales was due to the weakening demand for coal from China and India. Regarding debt repayment, Dileep said that his party had paid up to the US \$331.6 million in cash. This amount consists of principal Tranche amounting to US \$ 195.8 million and interest of US \$ 135.8 million. Since April 2018 the company has been paying the loan. Directorate Jenderal Pajak. ICW suspects that PT Bumi Resources Tbk and its subsidiaries had manipulated reports from 2003-2008, causing state losses of US \$ 620.49 million. The results of ICW calculations using a variety of primary data including audited financial reports show Bumi sales reports. during 2003-2008 it was US \$ 1.06 billion less than it was. As a result, during that time it was estimated that the state's loss from the shortage of Coal Production Funds revenue (royalty) reached the US \$ 143.18 million. The state loss from underpayment of taxes reached the US \$ 477.29 million.

Many previous studies have examined the effect of the previous year's audit opinion, profitability, audit tenure, and quality control systems on going concern audit opinion. Study conducted by Succession and [15] and [6] shows that previous year's audit opinion has an influence on going concern audit opinion, while [24] and [12] show previous 
years audit opinion has no significant relationship on the going concern audit opinion. This study concludes that when expressing an opinion, the auditor will pay attention to the previous year's audit opinion. The previous year's audit opinion can serve as a benchmark for the auditor to provide the current year's audit opinion. If the corporation received a going concern audit opinion last year, the auditor is likely to return the going concern audit opinion for that year.

Furthermore, profitability one of factor that effect on the going concern audit opinion. [14] and [25] show that the profitability does not have a significant effect on the going concern audit opinion. Meanwhile, [9] show that the profitability has a significant effect on the going concern audit opinion. This study concludes that profitability does not influence the acceptance of the continuous operations audit opinion. There is no significant relationship between profitability and going concern audit opinion due to the relatively high corporate financial leverage, meaning that an increase in the profit of a business entity is not matched by a decrease in company liabilities. [25] and [18] shows that the audit tenure has no significant effect on going concern audit opinion. Meanwhile, [24] shows that the audit tenure influences going concern audit opinion. This study concludes whether the length of the engagement that occurs between the auditor and the client does not influence the audit opinion based on professionalism and responsibility of the auditor's profession while on duty.

Following this phenomenon, it is concluded that giving an audit opinion by the auditor is very important because it affects the sustainability of the company. However, what is happening now is that there are still some auditors who have not been able to deliver early warnings in the form of going concern audit opinions on corporations that have problems with the survival of their companies. Failure to provide an audit opinion can have a negative impact on users of financial reports. Users of financial statements will certainly make the wrong response or conclude because of these errors. This means that it requires auditors to be more aware of potential problems that can affect the continuity of company operations. Based on the explanation above, the aim of this study is to examine the relationship between previous year's audit opinion, profitability, audit tenure, and quality control systems on going concern audit opinion.

\section{LITERATURE REVIEW}

\section{A. Agency Theory}

Agency Theory describes the relationship between the principal and the agent, in which the shareholders of a business entity are the principals, while management acts as the agent. Jensen and Mackling [11] defined agency theory as a relationship between the owner (principal) and manager (agent) in which the owner wants the manager to work for the interests of the owner, but sometimes managers act for their interests [4]. So that managers can work following the interests of the owner, it is necessary to control the performance of management. The agent is appointed by the principal to manage the company which is also the principal's delegation of authority to the agent in making company decisions on behalf of the owner. Thus, agents have more information than principals.

\section{B. Going Concern Audit Opinion}

Indonesian Institute of Certified Public Accountants [8] SA No.570, the auditor's consideration of the entity's capability to sustain its life. Continuous attention is one of the most important conceptions on which financial reports are based. Namely, the main responsibility of the director in assessing the appropriateness of preparing financial reports by relying on a policy of continuous concern and the responsibility of the auditor in convincing himself that the basis for sustainable business use is appropriate and stated accurately in the financial statements. An auditor who gives a going concern opinion/opinion for a business entity can have adverse effects on the business entity because this audit opinion is something that is not good for the survival of a business entity. However, the issuance of the going concern audit opinion by the auditor is expected so that the corporation can overcome the problems that exist in the corporation so that it can finally return to normal operations.

\section{Previous Years Audit Opinion}

The previous year's audit opinion is the audit opinion obtained by a business entity in the previous year or one year prior to the research year. Business entities that have received a going concern audit opinion in the past year are assumed to have problems in maintaining the sustainability of their business, thus enabling the auditors to return to their going concern audit opinion in the current year [24]. The previous year's going concern audit opinion was an important consideration for the auditor in releasing his going concern audit opinion for the next period.

\section{Profitability}

Profitability is the ratio in evaluating the capabilities of a company when chasing profits. Profitability ratios can provide a measure of management effectiveness in business entities. This can be seen through the profits the company gets from sales activities and investment income. The use of this ratio shows the efficiency of the corporation. Profitability is the ability of the company to generate profits from its capital, total assets, and sales. Therefore, long-term investors often use this ratio for the benefit of profitability analysis.

\section{E. Audit Tenure}

Auditor client tenure is shown through the duration of the year of the engagement between the company and the same auditor (KAP). The auditor's consideration when assessing the client's financial statements will have a good impact following a long working period, this is due to the reduced information asymmetry between the auditor and the corporation and the auditor's knowledge of the company's financial condition is getting better. The long period of the relationship between the auditor and the auditee is audit tenure. The auditor has had a relationship with the client for years, this means that the auditor views the client as a source of income, of course, this has the potential for a reduction in independence [12]. Audit tenure is a period of working relationship that occurs between the Public Accounting Firm (KAP) and the auditee. 


\section{F. Quality Control System}

According to Law Number 5 of 2011 concerning public accountants in article 18, it requires KAP to have a quality control system design. Quality control systems are closely related but not the same as auditing standards. In each assignment, KAP or Public Accountant must follow auditing standards. To ensure this, the Public Accounting Firm follows a quality control procedure that encourages compliance with standards with consistency in each assigned assignment. So, quality control is determined in the KAP while auditing standards are set in each assignment [2].

\section{HYPOTHESIS DEVELOPMENT AND CONCEPTUAL SCHEME}

The previous year's audit opinion is the audit opinion obtained by the company in the previous period or the year before the research year. A company that received a going concern audit opinion from the auditor in the previous year is considered to have difficulty in surviving its business continuity, thus enabling the auditor to give a going concern audit opinion again in the current year. The previous year's going concern audit opinion is an important material for the auditor's consideration when re-issuing a going concern audit opinion for the next period. In a study conducted by [23], we tested whether there was an influence on the previous year's audit opinion on going concern audit opinion. The results of his research stated that the previous year's audit opinion had an influence on the going concern audit opinion.

$\mathrm{H}_{1}$ : Previous year's audit opinion affects the going concern audit opinion

Regarding the relationship between profitability and going concern audit opinion, all corporations must be able to use all their resources to generate profits, and the profits obtained cannot be used to maintain business continuity. The smaller the profit margin of a business entity, the smaller the capacity of the corporation's business to earn a profit. This causes auditors to doubt the sustainability of their business entities, on the contrary, if the profit margins are large, the profitability of the business entities will be large, meaning that there will be greater corporate capabilities to get profits so that there is no doubt about the business continuity of the corporation [14].

\section{$\mathrm{H}_{2}$ : Profitability affects the going concern audit opinion.}

Audit tenure is the length of the KAP engagement with the same company. The longer the auditor's engagement with the same company, the more the auditor's understanding of the company will be. In this way, if there is a problem with business continuity, the auditors can quickly resolve the problem [20]. It is feared that the long-term relationship between the auditee and the auditor will interfere with the independence of the auditor. If the auditor's independence is lost, it will make it difficult for the auditor to provide a going concern audit opinion to reveal any doubts about the going concern of a business entity. It can be concluded that the longer the engagement between the auditee and the KAP, the less likely it is that a business entity will get a going concern audit opinion.

\section{$\mathrm{H}_{3}$ : Audit tenure affects the going concern audit opinion.}

In each assignment, KAP or Public Accountant must follow auditing standards. To ensure this is to carry out quality control procedures that encourage compliance with standards consistently in each assigned task [2]. Thus, a quality control system has been established for the KAP, then auditing standards are set for each assignment. Thus, the quality control system in an individual auditor organization will vary in nature and scope. This is because there are factors such as organizational structure, nature of work, size and level of autonomy of activities, as well as considerations about the aspect of funds and their use [16]. A quality audit process will show the determination of the audit opinion that will be issued by the auditor.

$\mathrm{H}_{4}$ : The quality control system affects the going concern audit opinion.

The previous year's going audit opinion is a crucial auditor's consideration in re-issuing a going concern audit opinion. In the following year, because business activities in a corporation are inseparable from the conditions experienced in the previous period. If in the previous period the company received a going concern audit opinion, it is likely that the auditor will want to give back the going concern audit opinion in the following year. This is due to considerations of losing public confidence in the sustainability of the business of a business entity as well as creditors and investors, which can then make it difficult for corporations to recover from difficult times.

\section{$\mathrm{H}_{5}$ : Previous year's audit opinion affects the going concern audit opinion through the quality control system}

The profitability ratio of a business entity can be measured by implementing return on assets (ROA). About the going concern audit opinion, the performance of all corporations is expected to benefit from all the resources they have, then the profits obtained will be used to maintain the sustainability of their corporate business. The smaller the profitability of a corporation, the smaller the capability of the corporation to make a profit, which may result in an indication of the auditor's doubt about the sustainability of the corporate business. Corporations that have received a going concern audit opinion are warned to improve their corporate performance. By establishing a quality control system, it is hoped that the company can carry out its operations effectively and efficiently to carry out its business.

$\mathrm{H}_{6}$ : Profitability affects the going concern audit opinion through the quality control system.

The auditor client tenure is shown through the length of the engagement year between the KAP auditors and the same corporation. The auditor's consideration when assessing the auditee's financial reporting can have a good impact in line with the enough length of the working period because there 
is reduced information asymmetry between the auditee and the auditor and the auditor's knowledge of the financial condition of the corporation is also getting better. The length of the engagement period between the auditee and the auditor is known as the audit tenure. When the auditor has had a relationship with the auditee for many years, this means that the auditor views the client as a source of income and can potentially lead to reduced independence [12]. It can be concluded that the longer the engagement between the auditee and the KAP is, the less chance the corporation will get a going concern audit opinion.

$\mathrm{H}_{6}$ : Audit tenure has an influence on the going concern audit opinion through the quality control system.

\section{RESEARCH METHODOLOGY}

The population used in this research is KAP that audited mining sector corporations listed on the IDX for the 20172019 period. In determining the KAP that audits the mining sector corporations, it can be seen through an independent auditor's report in a financial report. The time for distributing questionnaires was carried out from 1 December 2020 - 10 January 2021 through research in the form of a questionnaire to obtain data. The sample collection technique used in this research was the saturated sampling method. Saturated sampling is a method in which the existing population is used for sampling. The criteria that have been determined are following the objectives of the researcher so that they can provide the desired information. The specified criteria are:

(a) Mining companies listed on the IDX in 2017-2019.

(b) Public Accounting Firms that carry out audits in mining sector companies.

(c) Mining sector companies that release annual financial reports. The analysis technique used in this research is descriptive statistical test, and partial least square.

\section{RESUlTS AND DISCUSSION}

\section{A. Reliability and Validity Test}

Based on the table above, the result is that the AVE value is above 0.50 for all variables used in the research. Then it is concluded that the previous year's audit opinion variables, profitability, audit tenure, quality control system, and going concern audit opinion have their values above 0.50 with that result, all data variables are valid.

The composite reliability value for the entire construct is more than 0.70 , where these results have shown that all the constructs in this model have met the requirements. It can be concluded that all variables have a good composite reliability value or a good reliability value for each construct.

TABLE I: RELIABILITY AND VALIDITY TEST

\begin{tabular}{cccc}
\hline Variable & AVE & $\begin{array}{c}\text { Composite } \\
\text { Reliability }\end{array}$ & Cronbach Alpha \\
\hline PYAO & 1.000 & 1.000 & 1.000 \\
P & 1.000 & 1.000 & 1.000 \\
AT & 1.000 & 1.000 & 1.000 \\
QCS & 0.633 & 0.755 & 0.421 \\
GCAO & 1.000 & 1.000 & 1.000 \\
\hline
\end{tabular}

Based on the Table I above, it shows that in the previous year's audit opinion, it means that it is very reliable, for profitability it means that it is very reliable, for audit tenure, it means that it is very reliable, for the quality control system it gets a value of 0.421 which means it is quite reliable, for audit opinion going concern getting a value of 1,000 means that it is very reliable. Based on the table above, it shows that in the previous year's audit opinion, it means that it is very reliable, for profitability it means that it is very reliable, for audit tenure, it means that it is very reliable, for the quality control system it gets a value of 0.421 which means it is quite reliable, for audit opinion going concern getting a value of 1,000 means that it is very reliable

\section{B. Results}

The results of the hypothesis testing of this study can be seen in Table II.

TABLE II: PLS PATH ALGORITHM AND BOOTSTRAPPING

\begin{tabular}{crrr}
\hline Variable & $\begin{array}{c}\text { Path } \\
\text { Coefficient }\end{array}$ & T-Values & P-Values \\
\hline PYAO $\rightarrow$ GCAO & 0.679 & 8.005 & 0.000 \\
P $\rightarrow$ GCAO & -0.175 & 2.621 & 0.009 \\
AT $\rightarrow$ GCAO & -0.068 & 1.067 & 10.287 \\
QCS $\rightarrow$ GCAO & 0.039 & 0.612 & 0.541 \\
PYAU - QC - GCAO & 0.009 & 0.059 & 0.555 \\
P - QC - GCAO & 0.001 & 0.192 & 0.567 \\
AT - QC - GCAO & 0.004 & 0.456 & 0.649 \\
\hline
\end{tabular}

Based on the results of Table II above, previous year's audit opinion has a significant effect on the going concern audit opinion. This result of the previous year's audit opinion on the going concern audit opinion which has a tcount of 8.005 while $t_{\text {table }}$ is 1.98 so $t_{\text {count }}>t_{\text {table }}$. Furthermore, the significance level of the previous year's audit opinion was worth 0.000 , which means it is lower than the significance value of 0.05 $(0.000<0.05)$. It can be concluded that Ha is accepted and Ho is rejected, so it can be concluded that the previous year's audit opinion has a significant effect on the going concern audit opinion. It can be assumed that if a corporation that received a going concern audit opinion in the previous year could get a going concern audit opinion in the current year. According to [23] when publishing his opinion, the auditor pays close attention to the previous year's audit opinion. This opinion makes it the auditor's benchmark when issuing the current year's audit opinion. If in the previous year the corporation received a going concern audit opinion, the higher the chance of giving back going concern audit opinion by the auditor in the current year. This is due to the loss of public confidence in the sustainability of the business of a business entity, including creditors and investors, so that it can make it difficult for corporations to recover from the difficult conditions that have happened to corporations. [6] said that corporations that received a going concern audit opinion decision in the previous year related to business continuity operations are more likely to get a similar opinion decision in the current year. It can be concluded that if there is a corporation that gets a going concern audit opinion in the previous year, it will get a going concern audit opinion in the current year as well.

Profitability has a significant effect on the going concern audit opinion. This is obtained based on the test shows that the profitability in the going concern audit opinion has a $t_{\text {count }}$ 
of 2.621 while the $t$ table is 1.98 so $t_{\text {count }}>t_{\text {table. Furthermore, }}$ the significance level of the profitability is 0.009 which means it is smaller than the significance value of $0.05(0.009$ $<0.05)$. Thus, Ho is rejected, and Ha is accepted so that it can be concluded that profitability has a significant effect on the going concern audit opinion. The results of data processing carried out in this research show that corporations that receive a going concern audit opinion produce low profitability which results in indications of doubts given by auditors regarding the company's business continuity. The company received an emphasis indicating doubts about the sustainability of the company due to the company experiencing a deficit or decreased revenue

Audit tenure on going concern audit opinion, the results of the t-statistic test show that the audit tenure of the going concern audit opinion has a $t_{\text {count }}$ value of 1.067 while the $t_{\text {table }}$ is 1.98 so it can be seen that $t_{\text {count }}<t_{\text {table. }}$. Furthermore, the significance level of the audit tenure variable is 0.287 , which means it is greater than the significance value of $0.05(0.287>$ 0.05). This means that Ho is accepted, and $\mathrm{Ha}$ is rejected, so it can be concluded that audit tenure does not have a significant effect on going concern audit opinion. It can be concluded from this test that the audit tenure does not have a significant effect on going concern audit opinion. Even the period of the audit engagement with the auditee does not interfere with the independence of an auditor while on duty. The auditor will maintain his professional skepticism when carrying out the audit while still providing a going concern audit opinion if there is any doubt about the going concern of a corporation.

The quality control system in the going concern audit opinion has a t-count value of 0.612 while the $t_{\text {table }}$ is 1.98 so $\mathrm{t}_{\text {count }}<\mathrm{t}_{\text {table. }}$. Furthermore, the significance level of the quality control system is 0.541 , which means it is greater than the significance value of $0.05(0.541>0.05)$. Thus, Ho is accepted, and $\mathrm{Ha}$ is rejected so that it can be concluded that the quality control system does not have a significant effect on the going concern audit opinion. So, it can be concluded that the quality control system does not affect going concern audit opinion. Big four KAP must already have a quality control system with quality assurance, but there are still cases of auditors from these KAP neglecting their professional responsibilities. This indicates that there is a weakness of the quality control system and the auditor that has not implemented the quality control policies and procedures during the audit process properly.

Based on the total indirect effect test the effect of the previous year's audit opinion on the going concern audit opinion through the quality control system, the path analysis coefficient is 0.009 while the direct path analysis coefficient is 0.679 . This means that the value of the indirect path coefficient is smaller than the value of the direct path coefficient $(0.009<0.679)$. it can be concluded that the previous year's audit opinion does not have an indirect effect on the going concern audit opinion through the quality control system. According to the results of the previous year's audit opinion, it has a direct effect on going-concern audit opinion following direct testing. However, through indirect testing, the quality control system cannot influence the previous year's audit opinion to the going concern audit opinion. This is because in the auditing process the auditor will consider the results of the financial statements that have been prepared by the company, therefore this is one form of why the previous year's audit opinion does not affect going concern audit opinion through the quality control system.

Based on testing through the total indirect effect the profitability on the going concern audit opinion through the quality control system, the path analysis coefficient is 0.001 while the direct path analysis coefficient is -0.175 . This means that the value of the indirect path coefficient is greater than the value of the direct path coefficient $(0.001>-0.175)$. So, it can be concluded that profitability has an indirect effect on going concern audit opinion through the quality control system. When viewed from the auditor's point of view, the decision to provide an audit opinion will involve several stages of analysis. The auditor will consider the profitability of the results of operations, economic conditions that affect the company, the ability to pay debts, and future liquidity needs, this means that the results of the going concern audit opinion will come from the internal company, in terms of quality produced by the company. The results of this study are in line with attribution theory where the auditor in formulating an opinion so that it can provide the right opinion is influenced by the quality control system as an external attribution and professional science as an internal attribution within the auditor. The quality control system consists of methods that are documented in policies and procedures to ensure that the public accounting firm and its personnel fulfill their professional responsibilities to clients. The policies and procedures made contain elements of quality control to achieve the purpose of creating a quality control system, the purpose of which is to provide adequate assurance that KAP and all auditors comply with auditing standards, professional standards, and applicable regulations and legal provisions, KAP and partners. issue an audit report following the actual conditions.

Based on testing the total indirect effect the audit tenure on the going concern audit opinion through the quality control system, the path analysis coefficient is 0.004 while the direct path analysis coefficient is -0.068 . This means that the value of the indirect path coefficient is greater than the value of the direct path coefficient $(0.004>-0.068)$. Then it is concluded that audit tenure affects the going concern audit opinion through the quality control system. The auditor client tenure is shown through the length of the engagement year between the KAP auditors and the same corporation. The auditor's consideration when assessing the auditee's financial reporting can have a good impact in line with the enough length of the working period because there is reduced information asymmetry between the auditee and the auditor and the auditor's knowledge of the financial condition of the corporation is also getting better. The length of the engagement period between the auditee and the auditor is known as the audit tenure. When the auditor has had a relationship with the auditee for many years, this means that the auditor views the client as a source of income and can potentially lead to reduced independence [12]. 


\section{CONCLUSION, LIMITATIONS AND RECOMMENDATIONS}

This study aims to understand the effect of the previous year's audit opinion, profitability, audit tenure, and the quality control system on going concern audit opinion. Based on the results of data analysis obtained, it can be concluded that: Whereas the previous year's audit opinion had a significant effect on the going concern audit opinion. That profitability has a significant effect on going concern audit opinion. That the audit tenure does not have a significant effect on going concern audit opinion. That the quality control system does not have a significant effect on going concern audit opinion. Whereas the previous year's audit opinion did not affect the going concern audit opinion through the quality control system. That profitability affects the going concern audit opinion through the quality control system. That the audit tenure affects the going concern audit opinion through the quality control system.

The limitation of this study is collecting questionnaire data because currently Indonesia is being hit by the COVID-19 outbreak so that in distributing questionnaires many Public Accounting Firms (KAP) refuse to fill the form of questionnaires for mutual safety.

Based on the limitations of the research that have been described, it can be concluded that the following suggestions are:

1) For the next researcher, it is hoped that they can expand and develop the quality control system and add related variables that can influence going concern audit opinion to strengthen testing.

2) Business entities or corporations are expected to pay attention to various factors, especially financial conditions that can influence a going concern audit opinion because this opinion gives a warning to the company.

3) Investors are expected to pay attention to the level of the company's ability to run its business as a matter of consideration when making an investment decision.

4) Public Accounting Firms (KAP) are expected to consider factors that can affect the continuity of the company's business in providing opinions to produce audit reports that are useful in making decisions.

\section{REFERENCES}

[1] Anita, W. F. (2017). Analisis Faktor-Faktor Yang Mempengaruhi Opini Audit Going Concern Pada Perusahaan Manufaktur Yang Terdaftar Di Bursa Efek Indonesia. Jurnal Riset Keuangan Dan Akuntansi, 3(2), 87-108.

[2] Amjah, M. S. N., Hernawati, E., \& Arieftiara, D. (2020). Sistem Pengendalian Mutu Dan Audit Situation Terhadap Ketepatan Pemberian Opini Audit Melalui Professional Scepticism. 220-39.

[3] Darmawati, D., \& Puspitasari, W. (2018). Pengaruh Penerapan Sistem Pengendalian Mutu (SPM) Terhadap Kemampuan Auditor Dalam Mendeteksi Kecurangan. Jurnal Akuntansi, 4, 967-973.

[4] Ermawati, E., \& Aswar, K. (2020). Assessing Regional Finance Independence in Indonesia Local Governments. European Journal of Business and Management Research, 5(1), 1-5.

[5] Ghozali, I., \& Latan, H. (2015). Partial Least Squares Konsep, Teknik Dan Aplikasi Menggunakan Program SmartPls 3.0. Edisi Kedua, Semarang: Badan Penerbit Universitas Diponegoro.

[6] Ha, T.T., Nguyen, T. A. T., \& Nguyen, T.T. (2016). Factors Influencing The Auditor's Going -Concern Opinion Decision. Journal The 10th International Days of Statistics and Economics, Prague, September, (810), 1857-70.
[7] IAPI. (2013). Standar Professional Akuntan Publik (SA) 200. Jakarta: Salemba Empat.

[8] IAPI. (2012). Standar Professional Akuntan Publik (SA) 570. hlm 116. Jakarta: Salemba Empat.

[9] Irwanto, F., \& Tanusdjaja, H. (2020). Solvabilitas Terhadap Opini Audit Terkait Going Concern (Studi Pada Perusahaan Manufaktur Yang Terdaftar Di BEI Periode 2015). Jurnal Multiparadigma Akuntansi Tarumanagara, 2(1), 298-307.

[10] Jasmadeti., Widyastuti, T., \& Suyanto. (2018). Pengaruh Profesionalisme Auditor Dan Pertimbangan Tingkat Materialitas Terhadap Kualitas Audit (Studi Empiris Pada Auditor KAP Jakarta Pusat). Jurnal Ilmiah Ilmu Ekonomi , 6(12), 155-75.

[11] Jensen, M. C., \& Meckling, W. H. (2018). Theory of the Firm: Managerial Behavior, Agency Costs and Ownership Structure. Journal Value Summit: The Power of VE.

[12] Krissindiastuti, M., \& Rasmini, N. K. (2017). Faktor-Faktor Yang Mempengaruhi Opini Audit Going Concern. Accounting Global Journal, 1(1), 451-81.

[13] Lestari, P., \& Prayogi, B. (2017). Pengaruh Finacial Distress, Disclosure, Dan Opini Audit Tahun Sebelumnya Terhadap Opini Audit Going Concern. Journal Profita, 10(3), 388-98.

[14] Lie, C., Wardani, R. P., \& Pikir, T. W. (2016). Pengaruh Likuiditas, Solvabilitas, Profitabilitas, Dan Rencana Manajemen Terhadap Opini Audit Going Concern (Studi Empiris Perusahaan Manufaktur Di BEI). Jurnal Berkala Akuntansi Dan Keuangan Indonesia, 1(2), 84-105.

[15] Listantri, F., \& Mudjiyanti, R. (2016). Analisis Pengaruh Financial Distress, Ukuran Perusahaan, Solvabilitas, Dan Profitabilitas Terhadap Penerimaan Opini Audit Going Concern. Jurnal Media Ekonomi, 16(1), 163-75.

[16] Nurrohmah, S., \& Fathurochman, T. A. (2016). Pengaruh Sistem Pengendalian Mutu Kantor Akuntan Publik Terhadap Efektivitas Perencanaan Audit. Jurnal Riset Akuntansi Dan Keuangan, 4(1), 95766.

[17] Sarwoko, I. (2014). Pengaruh Ukuran KAP Dan Masa Perikatan Audit Terhadap Penerapan Prosedur Audit Untuk Mendeteksi Risiko Kecurangan Dalam Laporan Keuangan, Serta Implikasinya Terhadap Kualitas Audit (Survei Pada Kantor Akuntan Publik Anggota Forum Akuntan Pasar Modal). Jurnal Fakultas Ekonomi Universitas Pandjadjaran Bandung, XVIII, (01), 17.

[18] Puspaningsih, A., \& Analia, A. P. (2019). The Effect of Debt Default, Opinion Shopping, Audit Tenure and Company Financial Conditions on Audit Going Concern Opinion. Journal Review of Integrative Business and Economics Research, 9(2), 115-27.

[19] Putra, D. A., Anwar, A. S. H., \& Nur, T. (2017). Pengaruh Pertumbuhan Perusahaan, Kondisi Keuangan Perusahaan, Dan Opini Audit Tahun Sebelumnya Terhadap Opini Audit Going Concern. Jurnal Reviu Akuntansi Dan Keuangan, 6(1), 857-64.

[20] Setiyanti, S. W. (2012). Jenis- Jenis Pendapat Auditor (Opini Auditor) 66(2), hlm 37-39.

[21] SholehAsk, M. I. (2015). Audit Finansial, Audit Manajemen,Dan Sistem Pengendalian Intern. Jurnal Ekonomi Dan Hukum Islam, 5(2), $1-13$.

[22] Suksesi, G. W., \& Lastanti, H. S. (2016). Pengaruh Opini Audit Tahun Sebelumnya, Reputasi Auditor, Ukuran Perusahaan, Profitabilitas, Likuiditas, Dan Solvabilitas Terhadap Pemberian Opini Audit Going Concern. 1-15.

[23] Surianti, E., \& Purba, N. M. (2020). Faktor-Faktor Yang Mempengaruhi Opini Audit Going Concern Di Bursa Efek Indonesia. Jurnal EMBA: Jurnal Riset Ekonomi, Manajemen, Bisnis Dan Akuntansi, 8(1).

[24] Syahputra, F., \& Yahya, M. R. (2017). Pengaruh Audit Tenure, Audit Delay, Opini Audit Tahun Sebelumnya Dan Opinion Shopping Terhadap Penerimaan Opini Audit Going Concern Pada Perusahaan Manufaktur Yang Terdaftar Di Bursa Efek Indonesia Tahun 20132015. Jurnal Ilmiah Mahasiswa Ekonomi Akuntansi (JIMEKA), 2(3), 2-9.

[25] Witriasari, S. N., \& Arifin, A. (2018). Pengaruh Auditor Client Tenure, Reputasi Auditor, Ukuran Perusahaan, Dan Profitabilitas Terhadap Opini Audit (Studi Empiris Pada Perusahaan Yang Konsisten Terdaftar Dalam Indeks LQ45 Periode 2016-2018 ) Fakultas Ekonomi Dan Bisnis Universitas Muhammadiyah Surakarta Email: Sundarinovawitria@gmail.Com Fakultas E.Jurnal Ilmiah Ekonomi, (2009): 335-54. 